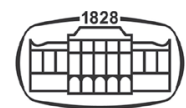

AKADÉMIAI KIADÓ

\title{
Egy középső vaskori leletegyüttes Mezőzomborról, Északkelet-Magyarország
}

\section{Archaeologiai Értesítő}

$146(2021) 93-106$

DOI:

$10.1556 / 0208.2021 .00003$

(c) 2021 A szerző(k)

\section{KÖZLEMÉNY}

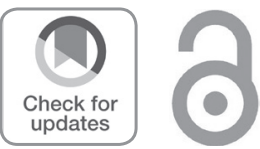

* Levelező szerzó.

E-mail: mogyipeti5@gmail.com

\author{
Mogyorós Péter ${ }^{1 *}\left(\right.$ i] - Bakos Gábor $^{2}$ (i) \\ ${ }^{1}$ Eötvös Loránd Tudományegyetem BTK, Régészettudományi Intézet; \\ 1088 Budapest, Múzeum körút 4/B \\ ${ }^{2}$ Herman Ottó Múzeum; 3529 Miskolc, Görgey Artúr u. 28.; \\ e-mail: bg.gp.ko@gmail.com \\ Kézirat beérkezett: 2021. május 7. Kézirat elfogadva: 2021. május 19.
}

\section{ABSZTRAKT}

E cikkben egy 2018 őszén, Mezőzombor-Békás-érről előkerült bronztárgyakból és borostyángyöngyökből álló együttes kerül bemutatásra. A lelettípusok tipokronológiai elemzése alapián, a Kr. e. 7. század 2. felére és a Kr. e. 6. század elejére keltezhetők. A különféle tárgyak analógiái arra utalnak, hogy ékszerekként, a ruházat dekorálására szolgáltak, az egyes leleteken látható viseleti nyomok alapján nem eltemetésre készítették az együttes elemeit. Eredeti kontextusuk bizonytalan, de valószínűsíthető, hogy egy temetkezés mellékleteiként kerültek a föld alá.

\section{KULCSSZAVAK}

középső vaskor, Vekerzug-kultúra, leletegyüttes, Mezőzombor-Békás-ér

\section{ABSTRACT}

In this article an assemblage made out of bronze and amber finds, that had been found in the autumn of 2018 in Mezőzombor-Békás-ér is going to be presented. The chronological analysis of the finds shows, that the assemblage can be dated to the second half of the $7^{\text {th }}$ century $\mathrm{BC}$ and the first half of the $6^{\text {th }}$ century BC. According to their analogies each type of objects in the assemblage can be interpreted as jewelleries or clothing decorations. Judging by the signs of wear on the finds we can assume that originally these were not made to be buried. The original context of the objects is uncertain - however it is probable that the artefacts belonged to a burial.

\section{KEYWORDS}

Middle Iron Age, Vekerzug culture, assemblage of finds, Mezőzombor-Békás-ér

\section{BEVEZETÉS, A LELETEGYÜTTES FELFEDEZÉSE}

2018 novemberében az észak-alföldi, Borsod-Abaúj-Zemplén megyei Mezőzombor-Békás-ér lelőhelyről egy bronztárgyakból és borostyángyöngyökből álló, középső vaskori együttes került elö (1. kép). A felfedezés azt követően történt, hogy a miskolci civil fémkeresős együttmüködés önkéntesei közül Molnár László és Győri Károly egy, a területen talált kis bronzpityke miatt felkeresték Bakos Gábort a miskolci Herman Ottó Múzeumban.

A leletmentés során először a tárgyak szóródási körzetét kellett lokalizálni, ez körülbelül $5 \mathrm{~m}^{2}$ területet érintett. Ezt követte a leletek kiemelése, amivel együtt járt a talaj folyamatos nyesése egészen a szántási szint aljáig, ahonnan már nem jött elő több fémlelet. A tárgyak 0-25 cm közti relatív mélységből, több szinten szóródtak, kizárólag a szántott talajrétegben. Régészetileg értelmezhető beásás nyomát nem lehetett megfigyelni.

Mivel nem ismert semmilyen régészeti objektum a leletek környezetéböl, így nem lehet biztosan meghatározni, hogy az előkerült tárgyak sírmellékleteknek vagy kincsegyüttes ele- 


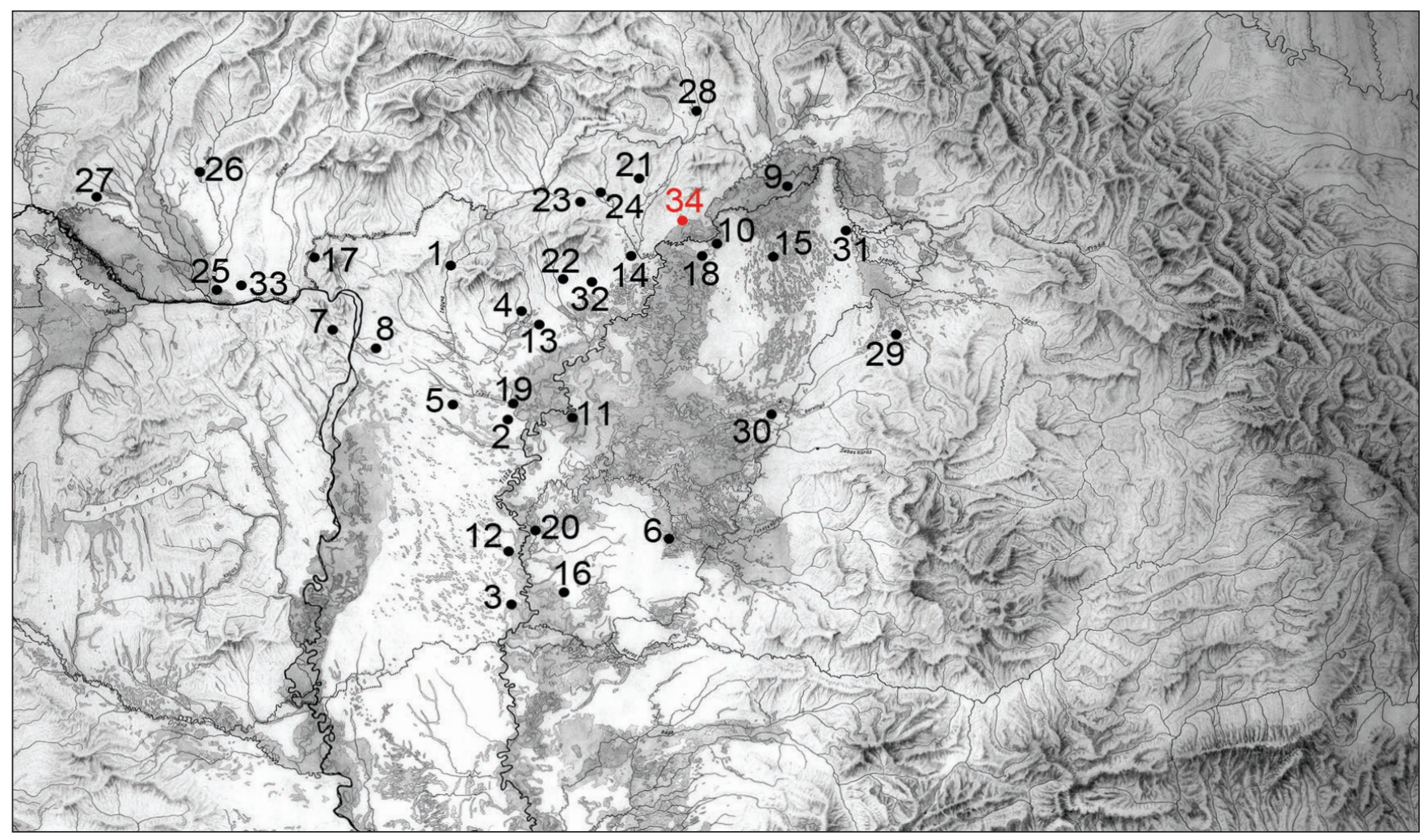

1. kép. A Vekerzug-kultúra lelőhelyei a Kr. e. 7. század második felében és a Kr. e. 6. század első felében (KozuBová 2019, Karte 1 nyomán, MezőzomborBékás-érrel kiegészítve)

Fig. 1. Sites of the Vekerzug culture from the second half of the $7^{\text {th }}$ century BC and the $6^{\text {th }}$ century BC (after KozuBové 2019 , Karte 1 with the addition of Mezőzombor-Békás-ér)

1: Mátraszele; 2: Cegléd-Hordógyár; 3: Sándorfalva-Eperjes; 4: Tarnadob; 5: Nyáregyháza; 6: Békéscsaba-Fényes; 7: Pomáz; 8: BudapestRákospalota; 9: Cigánd; 10: Tiszalök-Börtön; 11: Törökszentmiklós-Surján-Újtelep; 12: Csanytelek-Újhalastó; 13: Heves-Semelweis; 14: MuhiKocsmadomb; 15: Nyíregyháza-Közvágóhíd; 16: Orosháza-Gyopáros; 17: Vámosmikola-Istvánmajor; 18: Tiszavasvári-Csáradpart, Tiszavasvári-Dózsatelep; 19: Tápiószele-Szumrák; 20: Szentes-Vekerzug; 21: Alsótelekes-Dolinka-domb; 22: Eger-Nagy-Eged; 23: Dédestapolcsány-Verebce-bérc; 24: Sajószentpéter; 25: Chotín/Hetény IA és IB; 26: Nitra-Dolné Krškany/Nyitra; 27: Senec-Štrková kolónia/Szenc; 28: Ždaňa/Hernádzsadány; 29: Sanislău-Nisipăria/Szaniszló; 30: Ártánd-Zomlin puszta; 31: Nyírparasznya; 32: Mezőkövesd-Mocsolyás; 33: Modrany/Madar; 34: MezőzomborBékás-ér

meinek tekinthetők-e. A kérdést tovább nehezíti, hogy egyelöre kevés információval rendelkezünk a lelöhely környezetéről, nem tudunk se vaskori temetőről, se azonosítható, strukturált depozitumról. ${ }^{1}$

\section{LELETEK LEÍRÁSA}

1. Állatfejes csüngő. A lelet két darab háromfüles, egybeöntött bronzkarikából áll, a bronzkarikákat két rúd köti össze a felső akasztófüllel, a két rúdon is található egyegy fül. A csüngő alsó négy füle mind sérült, kettő el is tört. A másik kettőről lapos, tömör bronzkorongok lógnak le, a füleket megviselte e kiegészítők tartása, alul elvékonyodtak. A bronzkarikák és rudak találkozásánál két szarvasmarhafej található. A készítő a fej, a nyak és a szarvak vonalát ábrázolta, további részleteket nem dolgoztak ki. A két fej között egy rövid, rossz megtartású vasrúd található. A bronzfelületen hólyagosodás, korrodálódott vas és égésnyomok láthatóak. A tömör bronzkorongokat rövid kis karcolt vonalkákkal díszítették. A csüngő hossza $9,27 \mathrm{~cm}$, legnagyobb szélessége $6,04 \mathrm{~cm}$, vastagsága $0,5-0,7 \mathrm{~cm}$, a vasrúd vastagsága $0,8-0,9 \mathrm{~cm}$ (2. kép 1; 4. kép).

2. Csavart testü, pödrött végü nyílt karikaékszer két töredéke. A tárgy pödrött vége felé kiszélesedik. Felületén hólyagosodás, korrodált vas és égésnyomok. Mivel töredékes átmérőjét nem lehet pontosan meghatározni, körülbelül $12 \mathrm{~cm}$ lehetett, vastagsága $0,27-0,3 \mathrm{~cm}$, vége 0,42 cm-től 0,9 centiméterig szélesedik (2. kép 2).

3. Két végén kúpos, nyílt karikaékszer. Alakja eldeformálódott, felületén korrodált vas és égésnyomok. Átmérője körülbelül $4,5 \mathrm{~cm}$, testének vastagsága $0,15 \mathrm{~cm}$, kúpok legnagyobb vastagsága 0,29-0,32 cm (2. kép 3). 


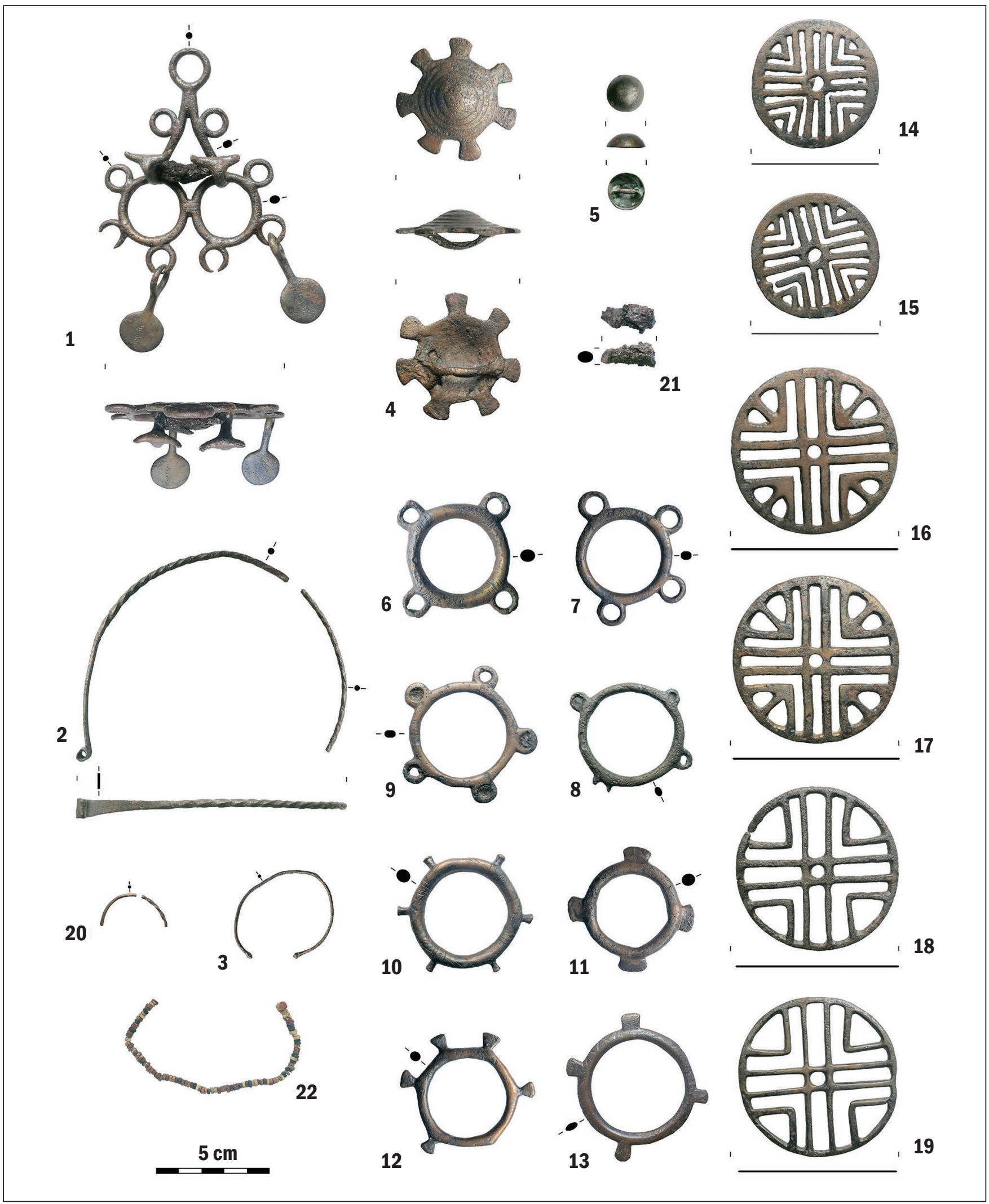

2. kép. A Mezőzombor-Békás-éri együttes. 1: Állatfejes csüngő; 2: csavart testû, pödrött végú karikaékszer; 3: kúpos végű karikaékszer; 4: koncentrikus körökkel díszített, csillag alakú bronzgomb; 5: domború bronzgomb; 6-9: füles bronzkarikák; 10-13: különféle dudorokkal rendelkező bronzkarikák; 14-19: áttört bronzkorongok; 20: bronz karikaékszerek töredékei; 21: vastöredék; 22: borostyángyöngyök (készítette A. Király A.)

Fig. 2. Contents of the assemblage. 1: bronze pendant with cattle heads; 2 : bronze twisted neck ring with an eyelet; 3: bronze earring with conical ends; 4: star shaped bronze button decorated with concentric circles; 5 : convex bronze button; 6-9: bronze rings with eyelets; 10-13: bronze rings with extensions; 14-19: bronze circular perforated discs; 20: fragments of bronze jewelleries; 21: iron fragment; 22: amber beads (created by A. Király A.) 
4. Öntött, csillag alakú bronzgomb. Hétágú, középen kúpos, négy koncentrikus körrel díszítették, hátoldalán egy akasztófül. Felületén hólyagosodás, korrodált vas és égésnyomok. Átmérője az ágakat nem beleszámítva $3,2 \mathrm{~cm}$, ágak hossza $0,7-0,8 \mathrm{~cm}$, vastagsága $0,3 \mathrm{~cm}$, magassága $0,9 \mathrm{~cm}$ (2. kép 4).

5. Öntött, domború bronzpityke. Hátoldalán egy akasztófüllel. Elő- és hátoldalán égésnyomok. Átmérője $1,55 \mathrm{~cm}$, vastagsága $0,14 \mathrm{~cm}$, magassága $0,58 \mathrm{~cm}$ (2. kép 5).

6. Öntött bronzkarika, oldalán négy füllel. Felületén hólyagosodás, korrodált vas és égésnyomok. A karikát a fülek közelében ferde karcolt vonalakkal díszítették. Átmérője 3,93-4 cm, vastagsága $0,45 \mathrm{~cm}$, fülek belső átmérője 0,48-0,63 cm (2. kép 6; 3. kép 3).

7. Öntött bronzkarika, oldalán négy füllel. Felületén hólyagosodás, korrodált vas és égésnyomok. Átmérője $4-4,07 \mathrm{~cm}$, vastagsága $0,64 \mathrm{~cm}$, fülek belső átmérője $0,25-0,58 \mathrm{~cm}$ (2. kép 7).

8. Öntött bronzkarika, oldalán négy füllel. Két alsó és két felső fül között enyhe deformálódás: széthúzás nyomai láthatók. A négy fülből az egyik letört, kettő betömődött. Felületén hólyagosodás és égésnyomok. Átmérője $4,22-4,39 \mathrm{~cm}$, vastagsága $0,43 \mathrm{~cm}$, az egy ép fül belső átmérője $0,2 \mathrm{~cm}$ (2. kép 8).

9. Öntött bronzkarika, oldalán öt füllel. Az öt fülből három betömődött. Felületén hólyagosodás és égésnyomok. Átmérője $4,41 \mathrm{~cm}$, vastagsága $0,45-0,47 \mathrm{~cm}$, ép fülek belső átméröje 0,22-0,41 cm (2. kép 9).

10. Öntött bronzkarika, hat darab szög alakú dudorral. A tárgyon enyhe deformálódás: használati nyomok láthatók, felszínén hólyagosodás és égésnyomok. A karikát ferde karcolt vonalakkal díszítették. Átmérője $4,18 \mathrm{~cm}$, vastagsága 0,52-0,6 cm (2. kép 10; 3. kép 1).

11. Öntött bronzkarika, oldalán négy lapos, széles dudorral. A tárgyon enyhe deformálódás: használati nyomok láthatók, felszínén hólyagosodás és égésnyomok. Átmérője $3,95 \mathrm{~cm}$, vastagsága $0,54 \mathrm{~cm}$ (2. kép 11).

12. Öntött, közel hatszög alakú bronztárgy. Öt sarkánál kiszélesedő, lapos dudorokkal. Felületén hólyagosodás, korrodált vas és égésnyomok. Átmérője $4,1 \mathrm{~cm}$, vastagsága $0,48 \mathrm{~cm}$ (2. kép 12).

13. Öntött bronzkarika, oldalán négy lapos, széles dudorral. Felületén hólyagosodás és égésnyomok. A karikát karcolt ferde vonalakkal díszítették. Átmérője $4,9 \mathrm{~cm}$, vastagsága 0,47-0,59 cm (2. kép 13; 3. kép 2).

14. Öntött, áttört, keresztmintás bronzkorong. Két-két rúd metszi egymást középen, a metszéspontjánál kör alakú átlyukasztással. Felületén hólyagosodás és égésnyomok. Átméröje $5,24 \mathrm{~cm}$, vastagsága $0,2 \mathrm{~cm}$ (2. kép 14).

15. Öntött, áttört, keresztmintás bronzkorong. Két-két rúd metszi egymást középen, a metszéspontjánál kör alakú átlyukasztással. Felületén hólyagosodás, korrodált vas és égésnyomok, belső mintázatán egy törés. Átmérő $5,22 \mathrm{~cm}$, vastagsága $0,2 \mathrm{~cm}$ (2. kép 15$)$.

16. Öntött, áttört, keresztmintás bronzkorong. Két-két rúd metszi egymást középen, a metszéspontjánál kör alakú átlyukasztással. Felületén hólyagosodás és égésnyomok. Átmérője $6,95 \mathrm{~cm}$, vastagsága 0,32 cm (2. kép 16).
17. Öntött, áttört, keresztmintás bronzkorong. Két-két rúd metszi egymást középen, a metszéspontjánál kör alakú átlyukasztással. Felületén hólyagosodás és égésnyomok. Átméröje 6,9-6,99 cm, vastagsága 0,3 cm (2. kép 17).

18. Öntött, áttört, keresztmintás bronzkorong. Két-két rúd metszi egymást középen, a metszéspontjánál kör alakú átlyukasztással. Felületén hólyagosodás. Átmérője 6,6$6,7 \mathrm{~cm}$, vastagsága $0,24 \mathrm{~cm}$ (2. kép 19).

19. Öntött, áttört, keresztmintás bronzkorong. Két-két rúd metszi egymást középen, a metszéspontjánál kör alakú átlyukasztással. Felületén hólyagosodás és égésnyomok, körvonalán egy ponton töréssel. Átmérője $6,6 \mathrm{~cm}$, vastagsága 0,26 cm (2. kép 18).

20. Két darab bronztöredék. Valószínüleg két külön karikaékszer részei lehettek. Egyik teste csavart, felületén hólyagosodás és égésnyomok, hossza 2,04 cm, vastagsága $0,15 \mathrm{~cm}$. Másik kör átmetszetü, felszínén hólyagosodás és égésnyomok, hossza $2,29 \mathrm{~cm}$, vastagsága $0,16 \mathrm{~cm}$ (2. kép 20).

21. Vastöredék. Rossz megtartású. Hossza $1,83 \mathrm{~cm}$, vastagsága 0,8-0,9 cm (2. kép 21).

22. 98 darab ép és még néhány töredékes borostyángyöngy. Mind az állatfejes csüngőt takaró földből jött elő. Felületükön enyhe égésnyomok. Méreteik változóak, a legnagyobb, hordó alakú gyöngy átmérője $0,43 \mathrm{~cm}$, magassága $0,34 \mathrm{~cm}$, a legkisebb, kör alakú gyöngy átmérője $0,27 \mathrm{~cm}$, magassága $0,12 \mathrm{~cm}$ (2. kép 22).

\section{A LELETEGYÜTTES TÁRGYAINAK KAPCSOLATAI ÉS IDŐRENDI HELYZETE}

A kis domború bronzpityke valószínüleg nem tartozott az együtteshez, mivel nem a többi lelettel együtt látott napvilágot (2. kép 5). Az Alföldön és az Északi-középhegységben a

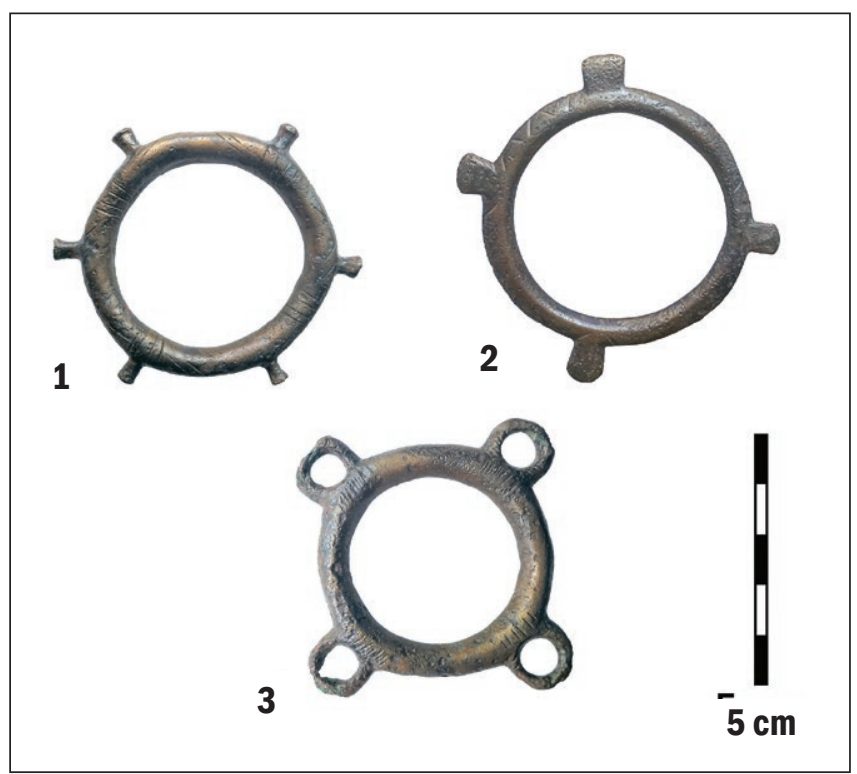

3. kép. Karcolással díszített bronzkarikák (készítette A. Király András)

Fig. 3. Bronze rings decorated with incisions (created by A. Király A.) 
kora és középső vaskorban is több lelőhelyen találkozni ezzel a tárgytípussal. ${ }^{2}$

Átmérője alapján nyakperecként értelmezhető a csavart testü, pödrött végü karikaékszer (2. kép 2). Ez a tárgytípus népszerü ékszernek számított Közép-Európa urnamezős időszakában, ám a Hallstatt-korra megfogyatkozik a számuk. ${ }^{3}$ A középső vaskor alatti, kelet-magyarországi lelőhelyekre pedig már egyáltalán nem jellemző. ${ }^{4}$ Ugyanilyen típusú, de masszívabb példányok viseletének szokása még a Kr. e. 7-6. században tovább élt a Balkánon, ${ }^{5}$ további analógiák a kelet-európai sztyeppén is megjelentek a Kr. e. 6-4. század között. ${ }^{6}$ Tipológiai szempontból a mezőzomborihoz legközelebbi párhuzam a ciumbrudi/csombordi Kr. e. 7-6. századi temetőből ismert, ez a darab is a vége felé kiszélesedik. ${ }^{7}$

A békás-éri együttes kúpos végü karikaékszere a Csombord/Ciumbrud-csoport lelőhelyeinek általános viseleti elemének tekinthető a Kr. e. 7. század közepe és a Kr. e. 6. század közepe között (2. kép 3). ${ }^{8}$ Valentin Vasiliev sztyeppei eredetűnek vélte a típust, ${ }^{9}$ ám ott csak későbbre, a Kr. e. 6. századtól a Kr. e. 4-3. századig keltezik. ${ }^{10}$ E tárgyak Donja Dolinára és a Vekerzug-kultúra kelet-magyarországi lelőhelyeire is eljutottak a Kr. e. 7. század második fele alatt. ${ }^{11}$ Az Alföld és az Északi-középhegység területén a legkésőbbi megjelenésüket Anita Kozubová a Kr. e. 6. század végére, a Kr. e. 5. század elejére helyezte. ${ }^{12}$

A Csombord-csoport csontvázas temetőiben, a legtöbb esetben a koponya két oldalán, a fülek környezetéből kerültek elő, ami alapján fülbevaló, esetleg hajkarikaként értel-

${ }^{2}$ Kora vaskori példák: Füzesabony-Kettőshalom (PATEK 1990, 4. t. 6-7; 7. t. 7-17, 19-20; 8. t. 14-16; 12. t. 15-16), Sirok-Akasztómáj (РАtek 1990, 23. t. 6-7), Tarnaörs-Csárdamajor (PATEK 1990, 27. t. 2), Füzesabony-Öregdomb (Gallus-Horváth 1939, Pl. 2, 4-5; Pl. 4, 4-6), Szeged-Öthalom (Gallus-Horváth 1939, 104, Pl. 48, 7-8). Középső vaskori példák: Nyékládaháza-Mezőnyék (GALlusHorváth 1939, Pl. 67, 7, 13-14), Nyíregyháza-Pazonyi utca (Kemenczei 2009, Taf. 52, 3), Dédestapolcsány-Verebce-bérc (Tóth 2012, 63, 3. t. 16-17), Szentes-Vekerzug (PÁrducz 1952, Pl. 49, 5-8; Pl. 54, 6-10).

${ }^{3}$ Metzner-Nebelsick 2002, 445.

${ }^{4}$ KemencZei 2009, 85.

${ }^{5}$ Gavranović 2011a, 213-214, Abb. 211.

${ }^{6}$ Петrehко 1978, 42, Таб. 29, 2; KLоснко 1997, 101, Tab. 1, 4.

${ }^{7}$ Ferenczi 1965, Fig. 8, 10.

${ }^{8}$ Marinescu 1984, 80; Kozubová 2013, 35; Kozubová 2019, 108.

${ }^{9}$ VAsiliev 1980, 92-93, 167.

${ }^{10}$ ПЕтренко 1978, 49, Таб. 38; МЕлюковА 1979, 231, Рис. 34, 2122.

${ }^{11}$ Gavranović 2011a, 216, Abb. 217. 1. Jan Chochorowski úgy vélte, hogy a Vekerzug-kultúra lelőhelyein a tárgytípus legkésőbb a Kr. e. 6. században jelent meg, ezt a következtetést elsősorban Alsótelekes-Dolinka-domb idősebb sírjainak leletanyaga alapján vonta le (Сносноrowski 1985, 65), hasonló véleményen volt Kemenczei Tibor is (Kemenczei 2002, 66). Patay Pál és B. Kiss Zsuzsa 2002-es tanulmányukban Alsótelekes idősebb sírjait és velük együtt a kúpos végű karikaékszerek első kelet-magyarországi megjelenését a Kr. e. 7. század második felére tették (PATAY-B. KIss 2002, 129-130).

${ }^{12}$ Kozubová 2013, 35, 44. lábjegyzet; Kozubová 2019, 108. mezhetők. ${ }^{13}$ Kivételt képeznek ez alól Simeria/Piski, Târnăvioara/Kisekemező és Aiud/Nagyenyed 19. század végén és a 20. század elején előkerült sírjai. Bár nem sikerült in situ pozícióban megfogni a leleteket, a felfedezők leírásai alapján a csontvázak karjain találták e tárgyakat. ${ }^{14}$ Orosia/Marosoroszi gyermeksírjában talált kúpos végű karikaékszerek esetében a szerzők lehetségesnek tartották, hogy karperecként funkcionálhattak, mivel nem a koponya közelében feküdtek. Azonban nem is a karoknál fogták meg őket, hanem a medence környezetében. ${ }^{15}$ Donja Dolina sírjaiban is a koponya két oldalán találhatók, fülbevalóként, vagy hajkarikaként határozhatók meg. ${ }^{16}$ Ezzel ellentétben az erdős sztyeppei leleteket karperecként értékelik a szakirodalomban, ${ }^{17}$ az erdélyiekkel szemben itt dokumentálni is lehetett e tárgyakat ebben a szituációban. ${ }^{18}$

A kelet-magyarországi lelőhelyeken nehezíti a funkció meghatározását, hogy a kúpos végű karikaékszerek hamvasztásos sírok mellékleteiként vagy szórványként ismertek. ${ }^{19} \mathrm{Az}$ eddigi publikációkban és tanulmányokban karperecként vagy fejdíszként (fülbevalóként, hajkarikaként) is értelmezték e tárgytípust. ${ }^{20} \mathrm{~A}$ mezőzombori példány átmérője alapján inkább tekinthető fülbevalónak, mint karperecnek.

Nem mindennapi tárgytípus a koncentrikus körökkel díszített, csillag alakú bronzgomb (2. kép 4). Ilyen leletek csak a Kárpát-medencében fordulnak elő a Csombord-csoport, a Vekerzug-kultúra és a Hallstatt-kultúra lelőhelyein. ${ }^{21}$ Georg Marinescu a Kr. e. 7-6. századra keltezte a típust, ${ }^{22}$ Tóth Farkas Márton az ismert darabok alapján a Kr. e. 7. század

${ }^{13}$ VAsiliev 1980, 92-93, 167; MARINESCU 1984, 80, Abb. 2, A/1a-b; Abb. 3, 8; Abb 4, 4a-b; Abb. 8, A/2a-b, B/1a-b; Abb. 11, 7.

${ }^{14}$ Herepey 1897, 3. ábra 10; Reinecke 1897 17, 5. ábra c; RoskA 1913, 234, 236, Fig. 2, 2; Fig 6, 2; 16, 20.

${ }^{15}$ UrsuțiU-URÁK 2017, 258, 261, Fig 1, 6-7; Pl. 2, 3-4.

${ }^{16}$ Truhelka 1904, Taf. 40, 2; Gavranović 2011a, 216, Abb. 217, 1.

${ }^{17}$ Петренко 1978, 49; МЕлюКова 1979, 231.

${ }^{18}$ АндРух-Тощев 1999, 36, 39, Рис. 8, 4.

${ }^{19}$ Piliny-Borsos (Patay 1955, 16. t. 10), Alsótelekes-Dolinkadomb (PATAY 1961, 6. t. 5, 9, 10, 13, 14), Ártánd-Zomlin (PÁrduCZ 1965, Pl. 20, 1-2; Pl. 22, 1-3), Tápiószele-Szumrák (PÁRDUCZ 1966, Pl. 39, 27; Pl. 50, 26-31; Pl. 64, 11-12), TiszavasváriCsárdapart (Kemenczei 2009, Taf. 121, 9), DédestapolcsányVerebce-bérc (Тóth 2012, 4. t. 6).

${ }^{20}$ Karperecként: Patay 1955, 66; PAtay-B. Kiss 2002, 114; Kemenczei 2002, 66; Kemenczei 2009, 85. Fejdíszként (mint hajkarika, fülbevaló vagy halántékgyürü/schläfenringe): TóTH 2012, 71; Kozubová 2013, 35; Kozubová 2019, 108. Párducz Mihály az ártándi darabok közül átmérőjük alapján kettőt fülbevalóként, egyet karperecként határozott meg (PÁRDUCZ 1965, 139).

${ }^{21}$ Teiuș/Tövis (Horedt 1953, 802, Fig. 11, 8), Ártánd-Zomlin (PÁRducz 1965, Pl. 22, 4, 6), Vaszar-Pörösrét (Mithay 1980, 64, Abb. 11, 9), Budeşti-Fînaţe/Szénásbudatelke (Marinescu 1984, 49, 81, Abb. 5, 7), Dédestapolcsány-Verebce-tető (Тóтн 2012, 63, 74, 3. t. 1).

${ }^{22}$ MarinesCu 1984, 77. 
közepe és a Kr. e. 6. század közepe közé szűkítette ezt az időintervallumot. ${ }^{23}$ Carola Metzner-Nebelsick úgy véli, túl kevés példányról tudunk ahhoz, hogy biztosan datálni lehessen e lelettípust. $^{24}$

Ezt a tárgytípust lószerszámként és dísztárgyként is értelmezték. ${ }^{25}$ Teiuș/Tövis 7. sírjában a csontváz medencéje alól került elö, ${ }^{26}$ Budești-Fînaţe/Szénásbudatelke 6. sírjában az elhunyt akinakésze mellett feküdt a csillag alakú bronzgomb. ${ }^{27}$ Más esetekben a hamvasztásos rítus vagy a bolygatás miatt nem lehet az eredeti kontextust meghatározni. E fenti két temetkezés alapján dísztárgyként, viseleti elemként lehet meghatározni a típust, nem lószerszámként.

Négy- és ötfüles bronzkarikák leginkább a Csombord-csoport és a Vekerzug-kultúra kelet-magyarországi lelőhelyeiről ismertek (2. kép 6-9). ${ }^{28}$ Emellett a Ferigile-kultúra és a nyugat-podóliai csoport lelöhelyein is elöfordulnak, ${ }^{29}$ Szlovákia területéről Václav Furmánek gyüjtötte össze e tárgytípus képviselöit. $^{30}$

Furmánek Podbiel/Podbjel 40. sírjának és Žaškov/Zsaskó együttesének alapján lehetségesnek tartotta a típus késő urnamezős korra való keltezést. Ám ezek időbeli elhelyezkedése bizonytalan, a szakirodalomban nem jellemző ennek a datálásnak a követése. ${ }^{31}$ Mikola Brandivskij a Kr. e. 7. század második felére teszi a füles bronzkarikák használatát, ${ }^{32}$ de több kutató nem tartja lehetségesnek a típus e rövid időintervallumba való keltezését. Georg Marinescu, Kemenczei Tibor a Kr. e. 7. század második fele és a Kr. e. 5. század eleje közé helyezik az ismert darabokat, ${ }^{33}$ Anita Kozubová úgy véli, az egész Hallstatt-korban számolni kell ilyen leletekkel, az viszont biztos, hogy Kelet-Magyarországon a Vekerzugkultúra temetőiből ismertek, így ebben a régióban a Kr. e. 7. század második fele során jelenhettek meg elöször. ${ }^{34}$

A füles bronzkarikákat a kutatás lószerszámként és viseleti elemként is értelmezi. ${ }^{35}$ Aiud/Nagyenyed és Firminiș/

\footnotetext{
${ }^{23}$ Tótн 2012, 72.

${ }^{24}$ MetZner-Nebelsick 2002, 326.

${ }^{25}$ Lószerszámként: PÁrducz 1965, 179; Metzner-Nebelsick 2002 326; Kemenczei 2009, 54; То́тн 2012 71-72. Övdíszként: MarinesCu 1984, 77. Hüvelydíszként: KozubovÁ-SKakov 2015, 309.

${ }^{26}$ Horedt 1953, 802, Fig. 11, 8.

${ }^{27}$ Marinescu 1984, Abb. 5, 7.

${ }^{28}$ Bottyán 1955, 60; VASILIEV 1980, 96, Pl. 16, 18; MARINESCU 1984, 79, Abb. 3, 3a-c; Abb. 9, 7; Сносновоwsкi 1985, 113, Abb. 38, 4-5; Kemenczei 2009, 54; Kozubová 2013, 54; Kozubová 2019, 99.

${ }^{29}$ VulPe 1967, Pl. 16, 5; БАНДРИвский 2005; Могилов 2008, 66, Рис. 124, 9-11.

${ }^{30}$ FurmáneK 1980, 44-45, Taf. 31, 843, 845-850.

${ }^{31}$ FurmáneK 1980, 45.

${ }^{32}$ БАНДРИВСКИЙ 2005.

${ }^{33}$ Marinescu 1984, 79; Kemenczei 2009, 54.

${ }^{34}$ Kozubová 2013, 54; Kozubová 2019, 99.

${ }^{35}$ Kantárszíjelosztóként: Сносновоwsкi 1985, 113, Abb. 39, D; AlmÁssy et al. 2001, 147-149, Kat. 109; Kat. 126; БАндРивский 2005; Могилов 2008, 66; Keмenczei 2009, 54; То́тн 2012, 72. Pártadíszként: Roska 1913, 234; Bottyán 1955, 60; M. Nepper
}

Fürményes esetében a csontvázak mellett feküdtek fegyverek között. Ezek alapján Valentin Vasiliev egyik meghatározást sem zárta ki biztosan. ${ }^{36}$ Simeria/Piski esetében a temetkezés felfedezői szerint a kérdéses tárgyat az elhunyt homlokán találták. ${ }^{37}$ Budeşti-Fînaţe/Szénásbudatelke 3. sírjában a négyés hatfüles karikákat az elhunyt gyermek mellkasán dokumentálták, ami alapján ruhadíszként klasszifikálhatók. ${ }^{38}$ Törökszentmiklós-Surján-Újtelepen a 34. sír zsugorított csontvázának koponyája és karja között leltek rá a tárgyra, itt nyaklánc részeként lehet kezelni. ${ }^{39}$ Valószínübb tehát, hogy viseleti elemekként kell tekinteni e típusra - nem lószerszámként. Anita Kozubová is rávilágított, hogy a fülek túl kicsik ahhoz, hogy a kantárszíjakat átfüzhessék rajtuk, ez a megállapítás az itt bemutatott darabokra is igaz. ${ }^{40}$ Kérdés, hogy hogyan hordták a mezőzombori példányokat? Hasonlóan a szénásbudatelki analógiákhoz, itt is több darab került egy együttesbe, így lehetséges, hogy a békás-éri példányok is egykor ruhadíszekként szolgáltak.

Az együttes részét képezte négy darab különféle dudorokkal rendelkező bronzkarika (2. kép 10-13). Kevés pontos párhuzammal rendelkeznek, a négy dudorral rendelkező példányokat Mikola Brandivskij a füles karikákkal együtt a Kr. e. 7. század második felére keltezte. ${ }^{41}$ Carola Metzner-Nebelsick szerint nem lehet ilyen pontosan datálni, ő a teljes Hallstatt-korra helyezi a tárgytípust. ${ }^{42}$ Bronzkarikák más-más jellegü és számú dudorokkal az oldalukon megtalálhatók Erdélyben, a Balkánon, néhány még Kelet-Magyarországon is, ${ }^{43}$ továbbá hasonló darabokat gyüjtött Klaus Kilian is Thesszáliából. ${ }^{44}$

Értelmezésük körül a korábbiakban is megjelent kettőség figyelhető meg: lószerszámokként és viseleti elemekként is szerepelnek a szakirodalomban. ${ }^{45}$ Ozd/Magyarózd 6. sírjában egy gyermekcsontváz medencéjénél fedeztek fel egy bronzkarikát, oldalán négy dudorral, a szerzők úgy vélték,

$\triangleright$ 1968, 62. Ruhadíszként: Marinescu 1984, 79. Csüngőként, nyaklánc részeként: Csalog-Kisfaludi 1985, 321; Parzinger et al. 1995, 49; Kozubová 2013, 54; Kozubová 2019, 99.

${ }^{36}$ VAsiliev 1980, 96. Vele együtt Furmánek is úgy vélte, hogy egyik lehetőség sem vethető el (FURMÁNEK 1980, 45).

${ }^{37}$ Roska 1913, 234.

${ }^{38}$ Marinescu 1984, 48, Abb. 3, 3a-c.

${ }^{39}$ Csalog-Kisfaludi 1985, 321, Abb. 7, 1-2.

${ }^{40}$ Kozubová 2013, 54.

${ }^{41}$ БАНДРИВСКИЙ 2005.

${ }^{42}$ Metzner-Nebelsick 2002, 453.

${ }^{43}$ Csanytelek-Tömörkényi utca (Hampel 1894, 265, 3. t. 6), Donja Dolina (Truhelka 1904, Fig. 51; Marić 1964, Tab. 15, 3), Alsótelekes-Dolinka-domb (Patay 1962, 16, 3. t. 4), Ciumbrud/ Csombord (Ferenczi 1965, Fig. 8, 9), Drenkova (Iaroslavschi 1973, 81, Fig. 3a-b; Fig. 4a-b), Ozd/Magyarózd (VAsiliev-ZrinYI 1974, 92, Pl. 11, 13), Hejőkeresztúr-Homokbánya (B. HellebRANDT 2001, 56, 4. kép 1), Erdut/Erdőd (Metzner-Nebelsick 2002, 688, Taf. 107, 18), Magdalenska Gora (Dular 2003, Abb. 82, 20), Grbavica (Gavranović 2011b, 52, Abb. 59, 7).

${ }^{44}$ Kilian 1975, Taf. 73, 28-37; Taf. 74, 1-11.

${ }^{45}$ Lószerszámként: CHOCHOROWSKi 1985, 114; B. Hellebrandt 2001, 56; БАНДРИВскИЙ 2005. Csüngőként: VAsILIEv-ZRINYI 1974, 92; MetZner-Nebelsick 2002, 453. 


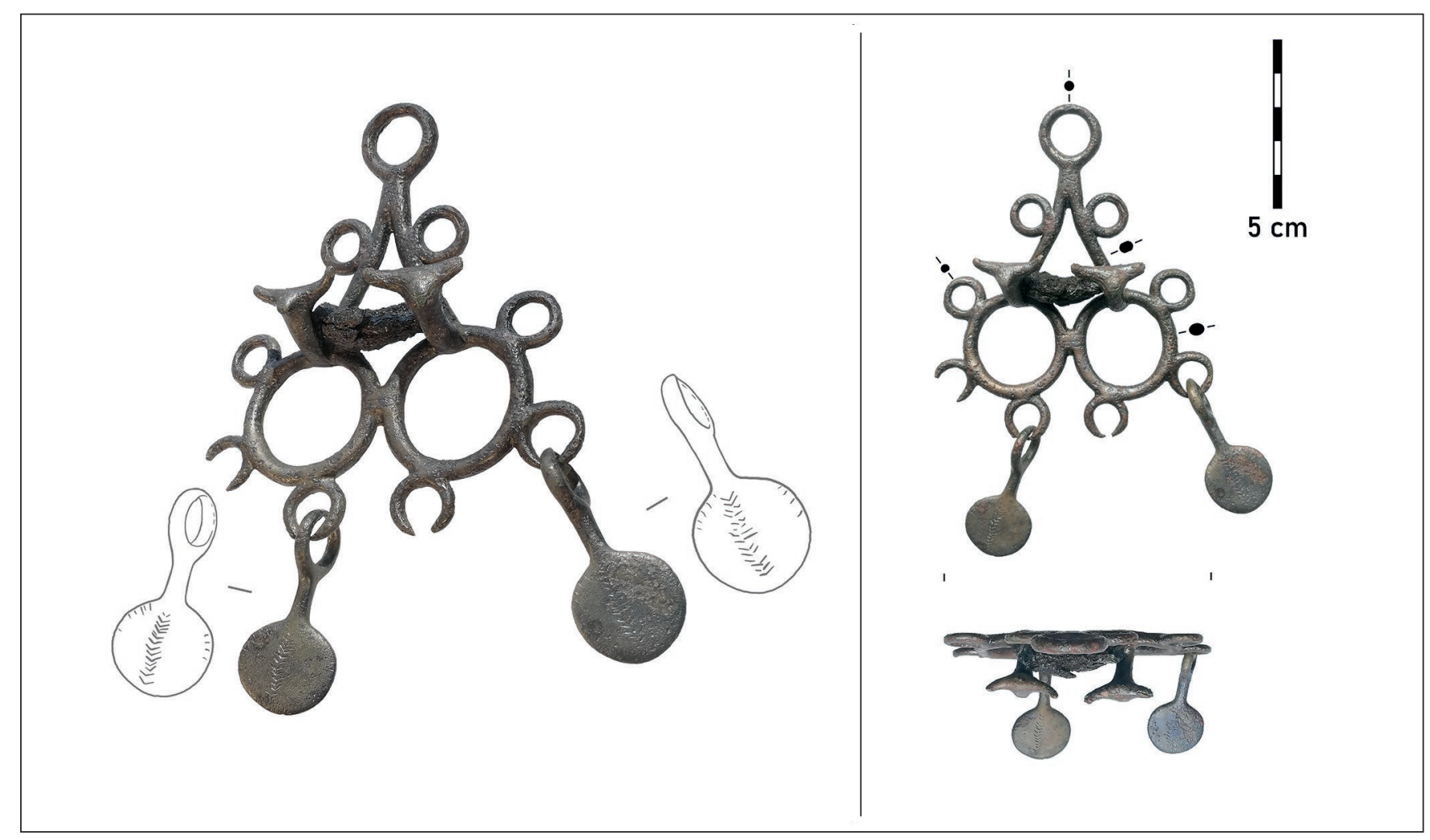

4. kép. Állatfejes csüngő (készítette A. Király A.)

Fig. 4. Bronze pendant with cattle heads (created by A. Király A.)

hogy övhöz tartozott. ${ }^{46}$ Nincs olyan eset, ahol egyértelműen lószerszámnak lehetne meghatározni hasonló tárgyakat, ezért a mezőzombori darabokra is inkább viseleti elemként kell gondolni.

Az együttesben hat darab kerék alakú, áttört díszes bronzkorong jelenik meg (2. kép 14-19). Az e tárgyakhoz - tipológiai szempontból - legközelebb álló párhuzamok a késő urnamezős és a Hallstatt-korban, Morvaországban, az Alpok keleti részén és a Kárpát-medence nyugati felén találhatók meg. ${ }^{47} \mathrm{E}$ területen az elökerülési kontextusuk változatos, strukturált depozitumokban, temetkezésekben és településeken is elöfordulnak. ${ }^{48}$ A rovnái csüngők kivételével, mindegyik rendelkezik egy-egy akasztófüllel. ${ }^{49}$ A Hallstattkultúrán kívül ritkán találkozni e tárgytípussal, azok nem

\footnotetext{
${ }^{46}$ VAsiliev-Zrinyi 1974, 92, 113, Pl. $4 \mathrm{~b}$.

${ }^{47}$ Chytrácek et al. 2018, 304-307, Abb. 17.

${ }^{48}$ Településekről: Celldömölk-Sághegy (PATEK 1968, Taf. 28, 33), Csákberény (PATEk 1968, Taf. 68, 3), Smolenice-Molpír (DušEKDušEk 1995, 70, Taf. 130). Temetkezésekből: Modřice-Sádky (Kos 2004, 279-280, Obr. 5, 8-9), Rovná (Chytrácek et al. 2018, 292, Abb. 8, A, B, 9-13). Depozitumokból: Thunau am Kamp (Lochner 1999, 181-183, Abb. 2, 7-10), Vaskeresztes-Magyarkeresztes (Mozsolics 1942, 157, Taf. 15, 26), Ravazd-Kisravazd (FeKete 1973, 345, Abb. 3, 30), Roštín "Vlčák" (Goleć-Kos 2020, 71, Fig. 2, 1-6).

${ }^{49} \mathrm{Az}$ akasztófülek tipológiájáról bővebben: GoLEĆ-Kos 2020, 7576.
}

rendelkeznek akasztófüllel. ${ }^{50}$ Ide sorolhatók a mezőzomboriak is.

$\mathrm{Az}$ áttört bronzkorongok mintázata edényeken is megjelenik. ${ }^{51}$ Ezek közül három is kiemelendő: az első a maiersch-i 38. sír egyik edénye, amelyen egy ember alak testén és a feje helyén többször is megjelenik ez a forma. ${ }^{52} \mathrm{~A}$ második a hallstatti temető 253. sírjának bronzszitulája, amin szintén megjelenik a korongok alakja. ${ }^{53}$ A harmadik Brno-HoláskyChrlice H2-es halomsírjának könyök alakú ivókürtje, amelynek külső felületén tünik fel ez a szimbólum. ${ }^{54}$

A leletek funkciójának meghatározására a sírleletek adnak választ. Modřice-Sádky K818-as sírjában két darab akasztófüles, stilizált kerék alakú bronzcsüngő feküdt egy női csontváz medencéje alatt, a bal láb két oldalán, övről
${ }^{50}$ Donja Dolina, Greda des Mato Petrović sen (Truhelka 1904, 125, Taf. 72, 21), Budeşti-Fînaţe/Szénásbudatelke (MARINEscu 1984, 48, Abb. 3, 7a-c), Cepari-Toplita (Popescu-Vulpe 1982, 87, 112, Fig. 4, B/b.)

${ }^{51}$ Sopron-Várhegy (Patek 1981, Abb. 1), Zagersdorf (Rebay 2002, Taf. 17, 68), Csönge (Lázár 1955, Fig. 3; Fig. 8; Taf. 34, 1-3), Süttő-Sánc-földek (V. VADÁsz 1983, Abb. 15), Ratkovce/Ratkóc (Müller 2012, 155, Taf. 183, 9), Vaszar-Pörösrét (РAtek 1993, Abb. 74, 4), Lábatlan (Patek 1993, Abb. 98, 6), Kismező (Patek 1993, Abb. 106, 3).

${ }^{52}$ Dobiat 1982, 282, Abb. $2,7$.

${ }^{53}$ Prüssing 1991, Taf. 28.

${ }^{54}$ Mirová-Goleć 2018, Tab. 27, 1a, 1c, 1d1. 
csünghettek le. ${ }^{55}$ Rovná 1 . halomsírjában minden bizonnyal egy négykerekű kocsira voltak szögelve. ${ }^{56}$ A Hallstatt-kultúrán kívüli, akasztófül nélküli analógiák Donja Dolina, Greda des Mato Petrović sen 10. sírjában és Budeşti-Fînaţe/Szénásbudatelke 3. sírjában is az elhunytak mellkasán feküdtek, ruhadíszként értelmezhetők. ${ }^{57}$ Valószínüleg a mezőzombori korongok is hasonló funkciót töltöttek be.

Nincs pontos analógiája a mezőzombori szarvasmarhafejes csüngőnek (2. kép 1; 4. kép). Formai szempontból Budeşti-Fînaţe/Szénásbudatelke 3. sírjának csüngője áll hozzá legközelebb. E tárgy az elhunyt medencéjének közelében feküdt, látszólag négy darab egybeöntött füles bronzkarikából áll. A fülekről háromszög alakú kisebb, lapos csüngők lógnak le. A tárgy felső részén két stilizált madárfej látható. A békás-érihez hasonlóan ennek a leletnek sincs pontos párhuzama, a publikáló Georg Marinescu balkáni és pannóniai stilizált madárfejeket ábrázoló csüngőkkel hasonlította össze, amelyek alapján ezt a darabot a Kr. e. 7. század második felére keltezte. ${ }^{58}$

A csüngőn látható két szarvasmarhafej kialakítása sematikus, hasonló megjelenésü állatalakokkal találkozni a kora, de föleg a középső vaskorban Kelet-Magyarország területén. Különböző tárgyakat, fegyvereket, tükröket, csörgőket, lószerszámokat dekoráltak ragadozó madarakkal, kecskékkel, őzekkel és nagymacskákkal. E díszítőművészet eredetét a kutatás a sztyeppei szkíta állatstílusban keresi. ${ }^{59}$ Azonban a szarvasmarhák ábrázolásának aránya - más élőlényekhez képest - elenyésző, mind a mi régiónkban, mind a sztyeppén. ${ }^{60}$ Jóval népszerübbek viszont a Vekerzug-kultúrától nyugatra. Itt elsősorban a Hallstatt-kultúra anyagából ismert bika protomés edényeket említhetjük. ${ }^{61}$

A szarvasmarhafejek mellett, a köztük található kis vasrúd az, ami különlegessé teszi ezt a csüngöt. Gyakorlati funkciója nincs, így feltételezhető, hogy szimbolikus tartalommal bírt, de hogy pontosan mit jelenthetett, azt nem lehet megmondani.

Egyedisége miatt valószínűsíthető, hogy helyi készítésű példány a békás-éri, ám létrehozásában lényegesek lehettek a szomszédos kultúrákkal tartott kapcsolatok. A szarvasmarhák gyakori ábrázolása mellett több olyan csüngő is előkerült a Hallstatt-kultúra lelőhelyeiről, amelyekről kisebb csüngők

\footnotetext{
${ }^{55}$ Kos 2004, 276-280, 289, Obr. 3, 3; Obr. 7.

${ }^{56}$ CHYtrÁCEK et al. 2018, 292, 304-307, Abb. 8, A, B, 9-13

${ }^{57}$ Truhelka 1904, 125, Taf. 72, 21; Marinescu 1984, 48, 79, Abb. 3 , Gr. 3. 7a-c.

${ }^{58}$ Marinescu 1984, 49, 79, Abb. 3, 6.

${ }^{59}$ PÁrducz 1973, 37-38; Kemenczei 2009, 57. Anita Kozubová úgy véli, hogy a Vekerzug-kultúra leletanyagában kevesebbféle tárgyon tűnnek fel állatábrázolások, mint a sztyeppén, azok közül is a legtöbb leegyszerüsített formában, így nem hordozzák magukban ugyanazt a jelentéstartalmat, mint a Kárpátoktól keletre (Kozuвová 2019, 155).

${ }^{60}$ PÁrducz 1973, 37-38; Ряькова 2005, 46-50; Kemenczei 2009, 57.

${ }^{61}$ Siegrried-Weiss 1979, 15-17, Karte I, Karte II, Taf. 1-3; Fekete 1985, 58-59, Abb. 6, 3-5; Abb. 16; Abb. 20, 9; РAтEK 1993, Abb. 65. 1, 3; Abb. 74, 1-2, 5; Abb. 94, 9-11; Abb. 105.
}

lógnak le, ezek inspirációként hathattak a mezőzombori darab elkészítéséhez. ${ }^{62}$

Borostyángyöngyök már a középső bronzkor óta ismertek az Alföldröl. ${ }^{63}$ A Hallstatt-korban jelentősen megugrik a számuk a korábbi időszakhoz képest az Alpok keleti részén, Szlovéniában, az Adriai partvidéken, a Balkán északnyugati részén, Kárpát-medencében, a kelet-európai erdős sztyeppén és a Kaukázus északi előterében is. ${ }^{64}$ Ebben az időszakban, a kelet-magyarországi régióban és a Vekerzug-kultúra más temetkezéseiben leginkább nyaki ékszerként találkozni borostyángyöngyökkel. ${ }^{65}$ A mezőzombori gyöngyök azonban a szarvasmarhafejes csüngő földjéből kerültek elő, elképzelhető, hogy nyaklánc helyett a csüngőt ékesítették (2. kép 22).

\section{A LELETEGYÜTTES FÖLDBE KERÜLÉSÉNEK IDEE}

A békás-éri leletek egyes tárgytípusai önmagukban nem alkalmasak egy szűk időintervallum lehatárolására. A kúpos végü fülbevaló, valamint a négy- és ötfüles bronzkarikák alapján az együttes nem lehet idősebb, mint a Kr. e. 7. század közepe. Ugyanezek alapján állapítható meg a Kr. e. 5. század eleje, aminél nem lehet fiatalabb. A csillag alakú bronzgomb a Tóth Farkas Márton-féle keltezés nyomán a Kr. e. 7. század közepe és a Kr. e. 6. század közepe közti periódusra tehető az együttes. E típus legfiatalabb képviselői az ártándi „fejedelmi” együttesből származnak, amelyet a Kr. e. 6. század első felére datálták az ott talált hydria alapján. ${ }^{66}$ Ujabban Conrad Stibbe nem zárta ki azt sem, hogy az ártándi leleteket a Kr. e. 7. század második felére lehessen tenni. ${ }^{67}$ Jelenlegi ismereteink szerint lehetséges a mezőzombori együttest a Kr. e. 7. század második felére és a Kr. e. 6. század elejére helyezni, arra az időszakra, amikor a Vekerzug-kultúra korai leletei jelentek meg a régióban. ${ }^{68}$ Ám, ahogy Carola Metzner-Nebelsick is megállapította, kevés koncentrikus körökkel díszített, csillag alakú bronzgomb ismert, így jövőbeli felfedezések változtathatnak ezen a keltezésen.

\section{A LELETEGYÜTTES FUNKCIÓJA}

Analógiáikat figyelembe véve a Békás-éren felfedezett tárgyak ékszerekként, ruhadíszekként értelmezhetők. Átmérője alapján a csavart testü, pödrött végü karikaékszer nyakperecnek tekinthető. A kúpos végü karikaékszerrel fejdíszként és karperecként is találkozni a szakirodalomban, a mezözom-

\footnotetext{
${ }^{62}$ Pomberger et al. 2020, 229-238.

${ }^{63}$ BECK-SPRINCZ 1981, 208.

${ }^{64}$ SPRINCZ 1993, 179-180, 183-184; STAHL 2006, 25; Кьоснко 2009, 416, Map 1; Map 2.

${ }^{65}$ Chochorowski 1985, 54-55; Kemenczei 2009, 90-91; Kozubová 2013, 47-48; Kozubová 2019, 99, 101-102.

${ }^{6}$ PÁRDUCZ 1965, 225-227.

${ }^{67}$ Stibie 2004, 38, Note 12, 148.

${ }^{68}$ Kemenczei 2000; Tóth 2012, 75; Kozubová 2019, 58-59, Karte 1.
} 
bori darab - a mérete miatt - fülbevalóként határozható meg. A csillag alakú, koncentrikus körökkel díszített bronzgomb a Teiuș/Tövis 7. sírjából és a Budeşti-Fînaţe/Szénásbudatelke 6. sírjából közölt példányok alapján övdíszként, talán hüvelydíszként értelmezhető, ám nem zárható ki, hogy a ruházat más elemét dekorálta a békás-éri együttesben. Párhuzamaikat tekintve a négy- és ötfüles bronzkarikák csüngőként, a viseletet kiegészítő tárgyakként értékelhetők. Hogy pontosan milyen szerepet láttak el a mezőzombori együttesben találtak, nem lehet biztosan megállapítani. Ezekhez hasonló rendeltetése lehetett a különféle dudorokkal rendelkező bronzkarikáknak is. A Békás-éren feltárt együttes áttört, kerék alakú bronzkorongjaihoz tipológiai szempontból Budești-Fînaţe/Szénásbudatelke 3. sírjában és Donja Dolina, Greda des Mato Petrović sen 10. sírjából ismert darabok állnak közel, ezek alapján a mellkasnál elhelyezkedő ruhadíszekként lehet rájuk tekinteni. A szarvasmarhafejes csüngő legközelebbi analógiájaként Budeşti-Fînaţe/Szénásbudatelke 3. sírjának stilizált állatfejes csüngőjére hivatkoztunk, ami a temetkezésben látott pozíciója alapján talán az elhunyt övéről csüngött le. Hogy hol viselte egykori tulajdonosa ezt a leletet, nem lehet biztosan megmondani. A mezőzombori csüngőt körülbelül 100 borostyángyöngy ékesítette.

A leleteken látható kopások és deformálódások azt jelzik, hogy az egyes darabok földbe kerülésük elött hosszú ideig használatban voltak. Ilyen elváltozások leglátványosabban a szarvasmarhafejes csüngő külső fülein látszanak, amelyeket megviselt a kisebb, korong alakú csüngők tartása, ezért anyaguk elvékonyodott, megsérült (2. kép 1; 4. kép), ez annak eredménye, hogy ezt a tárgyat intenzíven viselték, illetve használták. Kisebb deformálódások az egyik bronzkarikán is felfedezhetők (2. kép 11).

\section{AZ EGYÜTTES FÖLDBE KERÜLÉSÉNEK OKA: ÁLDOZATI/KINCSEGYÜTTES VAGY TEMETKEZÉSI MELLÉKLETEK}

Mivel a leleteket eredetileg tároló objektumot nem sikerült azonosítani, azt sem lehet biztosan megmondani, hogy áldozati együttes, vagy temetkezés maradványait sikerült e megfogni. A Ha C és Ha D periódusokból eddig kevés depó került elő Magyarország területéről. A fémek deponálásának szokása legintenzívebben a mai Franciaország területén figyelhető meg, onnan kelet felé csökken az ismert áldozati együttesek száma. ${ }^{69} \mathrm{E}$ depozitumok felépülhetnek egy funkciót ellátó leletekből, vagy különböző feladatra készült tárgyakból. Az együttesek elemei lehetnek egyidősek, vagy akár hosszú időn keresztül felhalmozottak. ${ }^{70}$ A tárgyak lehetnek ép állapotúak, rongáltak, de nyersanyagokat és félkész termékeket is találni. ${ }^{71} \mathrm{~A}$ mezőzombori fémeket nem rongálták meg, viseleti elemek, ami azt jelenti, hogy olyan együttesek

\footnotetext{
${ }^{69}$ Westhausen 2018, 136, Fig. 2.

${ }^{70}$ Westhausen 2018, 136-139, Fig. 11.

${ }^{71}$ Westhausen 2018, 146, Fig. 16.
}

közé tartozna, amelyek egy funkciót ellátó leletekből állnak össze.

Bronzékszerekből álló strukturált depozitumok Mezőzomborhoz legközelebb, a korszakban, a Hallstatt-kultúra morvaországi és a Kárpát-medence nyugati felének lelőhelyein fordulnak elő nagyobb számban. Elöbbi területen az ismert 18 együttesből 16 állt fémből készült viseleti elemekből, ${ }^{72}$ utóbbi régióban is a legtöbb kincslelet ékszerekből tevődött össze, ${ }^{73}$ ez alól kivétel a szitulát és cisztákat tartalmazó kurdi együttes. ${ }^{74}$ Szintén kivételt képez SmoleniceMolpír/Szomolány kora vaskori erődített településéről elökerült 6 együttes, amelyek közül egyikben sem az ékszerek dominálnak. Balták, tük, sarlók, lószerszámok alkották ezeket, néhány csüngö, karperec, gyöngy és fibula mellett. ${ }^{75}$ A 4. depó vas nyersanyagokat, fémek megmunkálására való eszközöket tartalmazott, egy fémmüves mester felszereléseként interpretálták. ${ }^{76} \mathrm{Az}$ Ikervár-Pinkóczi-dülőn feltárt bronzkincs elemei között viseleti tárgyak mellé más leletek is kerültek, például szűrőedény és egy üllő. ${ }^{77}$

A Vekerzug-kultúra területére azonban nem jellemzők a strukturált depozitumok. A szakirodalomban két együttesről merült fel, hogy depóként értékelhetők, ${ }^{78}$ ám eredeti kontextusa egyiknek sem ismert. Az egyik a zablákból, csörgőkből és harangokból álló nagytarcsai, ${ }^{79}$ a másik a Nižná Myšláról/Alsómislyéről közölt, fegyverekből és sarlókból összetevődő leletegyüttes. ${ }^{80}$

Fontos megemlíteni, hogy restaurálás előtt égés nyomait lehetett felfedezni a mezőzombori leleteken, ami alapján feltételezhető, hogy a tárgyak egy hamvasztásos temetkezés mellékletei lehettek. E rítus szórt és urnás változata gyakori jelenség a Vekerzug-kultúra temetőiben. ${ }^{81}$ Bár a békás-éri együttes fémekben jóval gazdagabb, mint egy átlagos sír e régióban, a középső vaskorban, nem példa nélküli, hogy egy temetőn belül néhány temetkezés mellékletszáma magasan felülmúlja a többiét. ${ }^{82} \mathrm{Az}$ áldozati vagy kincsegyüttesek hiánya és az égési nyomok jelenléte miatt valószínűbbnek tünik az a lehetőség, hogy sírmellékletekként határozhatók meg a Mezőzombor-Békás-éren talált leletek.

\footnotetext{
${ }^{72}$ Goleć et al. 2018, 51, 53.

${ }^{73}$ TerŽan 1990, 183; Kemenczei 1996, 471-476.

${ }^{74}$ PATAY 1987.

${ }^{75}$ ČAMBAL-MaKarová 2020.

${ }^{76}$ ČAmbaL-MaKarová 2020, 221, Fig. 7.

${ }^{77}$ NAGY et al. 2012, 6. t. 1-4.
}

${ }^{78}$ Egy harmadik, még közöletlen együttes sorolható a középső vaskorhoz, amely az Eötvös Loránd Tudományegyetem Régészettudományi Intézetének és a Hermann Ottó Múzeum munkatársai és a velük tartó önkéntes fémkeresősök kutatása során került elő Cserépfalu-Mésztetőről.

${ }^{79}$ BAKay 1971, 20-21, Fig. 4, 6.

${ }^{80}$ MiroššAYová 1980.

${ }^{81}$ PÁrducz 1973, 53; Сhochorowski 1985, 136; Kemenczei 2009, 29-34; Kozubová 2013, 207; Kozubová 2019, 141-142.

${ }^{82}$ Ilyenekre példa a Vekerzug-kultúra északkeleti lelőhelyeiről Tiszavasvári-Csárdapart 32. sírja (KemenCZei 2009, 155, Taf. 119, 15, 18-22; Taf. 120), valamint Ždaňa/Hernádzsadány 5/05-ös sírja (MiroššAYová 2015 80, Tab. 26, 1). 


\section{KÖSZÖNETNYILVÁNÍTÁS}

Győri Károly és Molnár László régészetbe vetett áldozatos munkájának köszönhetö, hogy a leletek közlésre kerülhettek. Köszönettel tartozunk V. Szabó Gábornak segítségéért és tanácsaiért.

\section{IRODALOM}

Almássy, Katalin-Cseh, János-Fodor, László-Gyucha, AttilaHavassy, Péter-B. Hellebrandt, Magdolna-Horváth, AttilaHorváth M., Attila-Istvánovits, Eszter-Kemenczei, TiborKulcsár, VAlÉria-M. Nepper, Ilona-Scholtz, RóberT-SzÉnÁszky, Júlia-VÁradi, AdÉL

2001 Katalógus. In: Havassy, P. (szerk.): Hatalmasok viadalokban. Az Alföld szkíta kora (Sie sind in Kämpfen siegreich. Das Zeitalter der Skythen in der Tiefebene). Gyulai katalógusok 10. Gyula, 129-185.

АндRух, СветлАнА-ТощЕв, ГЕНАДІ

1999 Могильник Мамай-Гора. Книга 1 (Burial Ground MamayGora. Book 1). Запорожье

BAKAY, KORNÉL

1971 Scythian Rattles in the Carpathian Basin and their Eastern Connections. Budapest.

БАндривский, МиколА С.

2005 Подільсько-Карпатський тип кінської упряжі VII ст. до н.э (Podil-Carpathian Type of Harness from $7^{\text {th }}$ c. ВC). Археологія Київ 4, 90-93.

Beck, Curt W.-Sprincz Emma

1981 A szegedi Móra Ferenc Múzeum bronzkori borostyánkő gyöngyeinek eredete (The origin of the Bronze Age amber int he Móra Ferenc Múzeum). Archaeologiai Értesítő 108, 206210.

BOTTYÁN, ÁRPÁD

1955 Szkíták a magyar Alföldön. RégFüz 1. Budapest.

CHOCHOROWSKI, JAN

1985 Die Vekerzug Kultur. Charakteristik der Funde. WarszawaKraków.

Chytrácek, Miloslav-Chvojka, Ondřej-Egg, Markus-John,

JAN-KYSELÝ, RenÉ-MicháleK, JAN-STRÁnSKÁ, PETRA

2018 Späthallstatt-zeitliches Fürstengrab von Rovná in Südböhmen. Symbolische Kunstform der Elite 6./5. Jahr. v. Chr., ihre Inspiration und Funktion. In: Bogusław, G.-Grossman, A.Piotrowski, W. (Hrsg.): Inspiracje i Funkcje Sztuki Pradziejowej i Wczesnośredniowiecznej. Biskopin-Wrocław, 283-321.

ČAmbal, Radoslav-MaKarová, Erika

2020 Hallstatt hoards from the Molpír hillfort in Smolenice. Zborník SNM 114 - Archeológia 30, 205-229.

CsAlog, Zsolt-Kisfaludi, JúliA

1985 Skytenzeitliches Gräberfeld in Törökszentmiklós-Surján-Újtelep. Acta Archaeologica Academiae Scientiarum Hungaricae 37, 307-344.

Dobiat, Claus

1982 Menschendarstellungen auf ostalpiner Hallstattkeramik. Eine Bestandsaufnahme. Acta Archaeologica Academiae Scientiarum Hungaricae 34, 279-322.

DULAR, JANEZ

2003 Halštatske nekropole Dolenjske (Die hallstattzeitlichen Nekropolen in Dolenjsko). Opera Instituti Archaeologici Sloveniae 6. Ljubljana. DOI: https://doi.org/10.3986/ 9789610502944
DUŠEK, Mikulas-DuŠEK, SigRID

1995 Smolenice-Molpír. Befestigter Fürstensitz der Hallstattzeit II. Materialia Archaeologica Slovaca 13. Nitra.

FeKete, MÁria

1973 Der Hortfund von Kisravazd. Acta Archaeologica Academiae Scientiarum Hungaricae 25, 341-358.

1985 Rettungsgrabung früheisenzeitlicher Hügelgräber in Vaskeresztes. Acta Archaeologica Academiae Scientiarum Hungaricae 37, 33-78.

FERENCZI, ȘTEFAN

1965 Cimitirul „scitic” de la Ciumbrud (Der „skythische” Friedhof von Ciumbrud). Acta Musei Napocensis 2, 77-105.

FURMÁNEK, VÁCLAV

1980 Die Anhänger in der Slowakei. Prähistorische Bronzefunde $\mathrm{XI} / 3$. München.

Gallus, SÁNDOR-Horváth, Tibor

1939 Un peuple cavalier préscythique en Hongrie: trouvailles archéologiques du premier age du fer et leurs relations avec l’Eurasie (A legrégibb lovasnép Magyarországon; korai vaskorból való régészeti hagyatéka és eurázsiai kapcsolatai). Dissertationes Pannonicae II/9. Budapest.

GAVRANOvić, Mario

2011a Die Spätbronze- und Früheisenzeit in Bosnien. Teil 1. Universitätsforschungen zur prähistorischen Archäologie 195. Berlin.

2011b Die Spätbronze- und Früheisenzeit in Bosnien. Teil 2. Universitätsforschungen zur prähistorischen Archäologie 195. Berlin.

Goleć, Martin-Kos, Petr

2020 The Hallstatt hoard of Roštín "Vlčák", Kroměříz district (CZ). In: Čižmář, I.-Čižmářová, H.-Humpolová, A. (eds): Jantarová stezka v proměnách času. Brno, 71-87.

Goleć, Martin-Fojtík, PAvel-RybáŘová, Klára

2018 Halštatský depot z Podomí - Zajbotu, okr. Vyškov (Hallstatt Hoard From Podomí - Zajbot, Vyškov District). Pravěk NŘ 26, 39-54.

HAMPEL, JózSEF

1894 A nemzeti múzeumi régiségtár gyarapodása. Archaeologiai Értesítő 14, 261-271.

B. Hellebrandt, Magdolna

2001 A szkíta kultúra emlékanyaga az Alföld és a Hegyvidék találkozásánál. In: Havassy, P. (szerk.): Hatalmasok viadalokban. Az Alföld szkíta kora (Sie sind in Kämpfen siegreich. Das Zeitalter der Skythen in der Tiefebene). Gyulai katalógusok 10. Gyula, 51-67.

Herepey, KÁroly

1897 A nagy-enyedi Múzeum némely régiségeiről. Archaeologiai Értesítő 17, 63-68.

HOREDT, KurT

1953 Cercetările arheologice din regiunea Hoghiz-Ugra şi Teiuș. Materiale şi cercetări arheologice 1, 785-815.

IAROSLAVSCHI, EUGEN

1973 Un depozit de bronzuri de la Drencova. (jud. Caraș-Severin) (Un dépot de bronzes de Drencova - départment CarașSeverin). Banatica 2, 79-84.

Kemenczei, Tibor

1996 Zur Deutung der endbronze- und früheisenzeitlichen Depotfunde Ungarns. In: Schauer, P. (Hrsg.): Archäologische Forschungen zum Kultgesehen in der jüngeren Bronzezeit und frühen Eisenzeit Alteuropas. Kolloqium Regensburg 1993. Regensburger Beiträge zur Prähistorischen Archäologie 2. Bonn, 451-480. 
2000 Adatok a szkítakor kezdetének kérdéséhez az Alföldön (Beiträge zur Frage des Anfangs der Skythenzeit auf der ungarischen Tiefebene). Folia Archaeologica 48, 27-53.

2002 Beiträge zur Schmuckmode der Alföld Gruppe skythischer Prägung (Adatok a szkíta jellegü Alföld-csoport ékszerdivatjához). Folia Archaeologica 49-50, 29-77.

2009 Studien zu den Denkmälern skytisch geprägter Alföld Gruppe. Inventaria Praehistorica Hungariae 12. Budapest.

KiLian, Klaus

1975 Fibeln in Thessalien von der mykenischen bis zur archaischen Zeit. Prähistorische Bronzefunde XIV/2. München.

KLоснко, Lubov S.

1997 Scythian Metal Neck Jewelry. Folia Praehistorica Posnaiensia 8, 99-120.

2009 Amber in Garments of Populations of Scythia (Ways and Forms of Reception). Baltic-Pontic Studies 14, 415-438.

Kos, Petr

2004 Pohřby țen $\mathrm{z}$ doby halštatské v Modřicích u Brna. In: Chvojka, O. (Hrsg.): Popelnicová pole a doba halštatská. Př́íspěvky z VIII. konference, Ĉeské Budějovice 22.-24. 9. 2004. Archeologické výzkumy v jiţních Ĉechách Supplementum 1. Ĉeské Budějovice, 271-292.

Kozubová, Anita

2013 Pohrebiská vekerzugskej kultúry v Chotíne na juhozápadnom Slovensku (Die Gräberfelder der Vekerzug-Kultur in Chotín in der Südwestslowakei). Dissertationes archaelogicae Bratislavenses 1. Bratislava.

2019 "Something happened in the east but more in the west and south." Einige kritische Bemerkungen zu östlichen Einflüssen in der Vekerzug-kultur. Musaica Archaeologica 4/1, 55-185.

Kozubová, Anita-Skakov, Alexander

2015 Einige kritische Bemerkungen zur Datierung der Dolche vom Typ Posmuş und ihrer kaukasischen Parallelen. In: Szathmári, I. (Hrsg.): An der Grenze der Bronze- und Eisenzeit. Festschrift für Tibor Kemenczei zum 75. Geburtstag. Budapest, 301-315.

LÁZÁR, JENŐ

1955 Hallstatt-kori tumulusok a Ság-hegy távolabbi környékéről (Hallstattzeitliche Tumuli aus der weiteren Umgebung des Ságberges, Westungarn). Archaeologiai Értesítő 82, 202-211.

LOCHNER, Michaela

1999 Ein Schmuckdepot der Urnfelderzeit aus Thunau am Kamp, Niederösterreich. Archaeologia Austriaca 82-83, 181-186.

MARIĆ, ZdRAVKo

1964 Donja Dolina. Glasnik Arheologija 19, 5-128.

Marinescu, Georg

1984 Die jüngere hallstattzeit in Nordostsiebenbürgen. Dacia 27, 47-83.

Мелюкова, Анна I.

1979 Скифия и фракийский мир. Москва.

Metzner-Nebelsick, Carola

2002 Der „Thrako-Kimmerische” Formenkreis aus der Sicht der Urnenfelder- und Hallstattzeit im südöstlichen Pannonien. Vorgeschichtliche Forschungen 23. Rhaden/Westf.

MiroššAYová, ElenA

1980 Depot Ţelených predmetov z Nižná Myšla (Depot von Eisengegenständen aus Nižná Myšla). Slovenská Archeológia 28/2, 383-394.

2015 Pohrebisko v Ţdani. v kontexte vyvoja severného Potisia v dobe halštatskej. Archaeologica Slovaca Monographiae Studia 24. Nitra.

Mirová, Zuzana-Goleć, Martin

2018 Hallstatt Magnate Graves from Brno-Holásky 1 and 2 in the Central European Context. Archaeologiae Regionalis Fontes 13. Olomuc.
MithaY, SÁNDOR

1980 A vaszari koravaskori temető és telephely (Gräberfeld und Siedlung von Vaszar aus der Früheisenzeit). Archaeologiai Értesítő 107, 53-78.

МогИЛОв, ОЛЕКСАНдР Д.

2008 Спорядження коня скіфської доби у Лісостепу Східної Європи. Київ-Кам"янець Подільський.

Mozsolics, Amália

1942 A magyarkeresztesi (Vas megyei) bronzlelet (Die Bronzefund von Magyarkeresztes Kom. Vas). Archaeologiai Értesítő 3, 155-161.

MÜller, Sebastian

2012 Smolenice-Molpír, Sered' und Ratkovce. Studien zu Siedlung der frühen Eisenzeit in der Südwestslowakei. Teil 1. Universitätsforschungen zur prähistorischen Archäologie 220. Bonn.

Nagy, Marcella-Sümegi, Pál-Persaits, Gergő-Gulyás, SándorTÖröCSIK, TÜNDE

2012 Vaskori bronzkincs Ikervár határában. Megjegyzések a hallstatt kori kultuszélet rekonstruálásához a régészeti és természettudományos vizsgálatok tükrében (Eisenzeitlicher Bronzeschatzfund in der Nähe von Ikervár. Kommentare zu der Rekonstruktion des kultischen Lebens zur HallstattPeriode im Spiegel archäologischer und naturwissenschaftlicher Untersuchungen). Savaria 35, 99-133.

M. NEPPER, ILONA

1968 Szkíta kori leletek a Déri Múzeumból (Adatközlés) (Scythian Finds in the Déri Museum (Publication of data)). A debreceni Déri Múzeum Évkönyve 1966-1967, 53-65.

PÁRdUCZ, MiHÁLY

1952 Le cimetière hallstattien de Szentes-Vekerzug. Acta Archaeologica Academiae Scientiarum Hungaricae 2, 143-172, 402428.

1965 Graves from the Scythian Age at Ártánd (county Hajdú-Bihar). Acta Archaeologica Academiae Scientiarum Hungaricae 17, 137-231, 417-446.

1966 The Scythian Age cemetery at Tápiószele. Acta Archaeologica Academiae Scientiarum Hungaricae 18, 35-91, 345-408.

1973 Probleme der Skythenzeit im Karpatenbecken. Acta Archaeologica Academiae Scientiarum Hungaricae 25, 27-63.

Parzinger, Hermann-Nekvasil, Jindra-Barth, Fritz Eckart

1995 Die Býćí skála-Höhle. Ein hallstattzeitlicher Höhlenopferplatz in Mähren. Römisch-Germanische Forschungen 54, Mainz.

PATAY, PÁL

1955 Szkíta leletek a nógrádi dombvidéken. Folia Archaeologica 7, 61-74, 332-336.

1961 Az alsótelekesi vaskori temető (Cimitière de lâge du fer à Alsótelekes). Folia Archaeologica 13, 27-50, 323-329.

1962 Újabb ásatások az alsótelekesi vaskori temetőben (Nouvelles fouilles au cimitière de lâge du fer à Alsótelekes). Folia Archaeologica 14, 13-21.

1987 Einige Worte über die Zisten von Kurd (Néhány szó a kurdi cisztákról). Folia Archaeologica 38, 129-140.

PataY, Pál-B. Kiss, Zsuzsa

2002 Az Alsótelekes-Dolinkai szkítakori temető közöletlen sírjai (az 1962. és 1964. évi feltárás eredményei) (Die unpublizierten Gräber des skythenzeitlichen Gräberfeldes von AlsótelekesDolinka [Die Ergebnisse der Freilegungen der Jahre 1962 und 1964]). Folia Archaeologica 49-50, 79-141.

Patek, ERzséBet

1968 Die Urnfelderkultur in Transdanubien. Archaeologia Hungarica 44. Budapest.

1981 Die Anfänge der Siedlung und des Gräberfeldes von SopronBurgstall. In: Eibner, C.-Eibner, A. (Hrsg.): Die Hallstatt kultur. Bericht über das Symposium in Steyr 1980 aus Anlaß der Internationalen Ausstellung des Landes Oberösterreich. Linz, 93-136. 
1990 A Szabó János Győző által feltárt „preszkíta” síranyag. A Füzesabony-Mezőcsát típusú temetkezések újabb emlékei Heves megyében (Die von János Győző Szabó freigelegten „preskythischen” Grabfunde. Die neueren Denkmäler der Bestattungen des Typ Füzesabony Mezőcsát im Komitat Heves). Agria - Az Egri Múzeum Évkönyve 25-26, 61-118.

1993 Westungarn in der Hallstattzeit. Acta Humanoria 7. Weinheim. ПЕТРЕНКО, ВЛАДИМИРОВА Г.

1978 Украшения Скифии VII - III вв. до н. э. Свод археологический источников Д1-4. Москва.

Pomberger, Beate Maria-Grömer, Karina-Mühlhans, JörgTOPA, DAN

2020 Schlitzbommeln und Anhänger - Klingender Trachtschmuck aus der Býčí skála-Höhle bei Brünn. Mitteilungen der Anthropologischen Gesellschaft in Wien 150, 215-242.

Popescu, Emilia-Vulpe, Alexandru

1982 Nouvelles decouvertes du type ferigile. Dacia 26, 77-114.

PRÜssing, GERLINDE

1991 Die Bronzegefäße in Österreich. Prähistorische Bronzefunde II/5. Stuttgart.

\section{Pusztai, Tamás}

2008 232. Mezőzombor, Békás-ér. In: Kisfaludi, J. (ed.): Régészeti kutatások Magyarországon 2007 (Archaeological Investigations in Hungary 2007), Budapest, 247.

Ряькова, ТАтьяна

2005 Образы звериного стиля в эпоху скифской архаики. Археологический сборник Государственного Эрмитажа $37,42-67$.

Rebay, Katharina

2002 Die hallstattzeitliche Grabhügelgruppe von Zagersdorf im Burgerland. Wissenschaftliche Arbeiten aus dem Burgerland 107. Eisenstadt.

REINECKe, PÁL

1897 Magyarországi skytha régiségek. Archaeologiai Értesítő 17, $1-27$.

Roska, MárTon

1913 Skytha sírok Piskiról. Dolgozatok az Erdélyi Nemzeti Múzeum Érem- és Régiségtárából 4, 233-243.

Siegrried-Weiss, Anita

1979 Der Ostalpenraum in der Hallstattzeit und seine Beziehungen zum Mittelmeergebiet. Hamburger Beiträge zur Archäologie 6. Hamburg.

SPRINCZ, EMMA

1993 Veneter - Skyten - Bernsteinhandel. In: Beck, C. W.-Bouzek, J. (eds): Amber in Archaeology. Praha, 179-186.
STAHL, CHRISTA

2006 Mitteleuropäische Bernsteinfunde von der Frühbronze- bis zur Frühlatènzeit. Ihre Verbreitung, Formgebung, Zeitstellung und Herkunft. Würzburger Studien zur Sprache und Kultur 9. Dettelbach.

Stibbe, Conrad M.

2004 Eine Bronzehydria mit menschlichen Protomen (Protomédíszes bronzhydria) Bulletin du Musée Hongrois des BeauxArts 101, 31-55, 145-158.

TERŽAn, BibA

1990 Starejša železna doba na Slovenskem Štajerskem (The Early Iron Age in Slovenian Styria). Katalogi in monografije 25. Ljubljana.

Tóth, Farkas Márton

2012 Korai szkítakori sírok Dédestapolcsány-Verebce-tető lelőhelyen (Early Scythian Age Graves at the site of Dédestapolcsány-Verebce-tető [NE Hungary]). A Herman Ottó Múzeum Évkönyve 51, 63-91.

Truhelka, Ĉriro

1904 Der vorgeschichtliche Pfahlbau im Savebette bei Donja Dolina (Bezirk Bosnich-Gradiška). Wissenschaftliche Mitteilungen aus Bosnien und der Hercegovina 9. Wien.

Ursuțiu, Adrian-Urák, Malvinka

2017 Iron Age girl in a Bronze Age pit? A child burial of the Ciumbrud cultural group from Orosia (Marosoroszi), Mureş County. In: Gogâltan, F.-Ailincăi, S.-C. (eds): Settlements of Life and Death. Studies from Prehistory to Middle Ages. Proceedings of an International Colloquium Tulcea, $25^{\text {th }}-28^{\text {th }}$ of May 2016. Cluj-Napoca, 255-272.

V. VADÁsZ, Éva

1983 Előzetes jelentés egy koravaskori halomsír feltárásáról Süttőn (Vorbericht über die Erschließung eines früheisenzeitlichen Hügels in Süttő). Communicationes Archaeologicae Hungariae, $17-54$.

VASILIEV, VALENTin

1980 Sciţii agatîrşi pe teritoriul României. Cluj-Napoca 1980.

Vasiliev, Valentin-Zrinyi, Andrei

1974 Necropola scitică de la Ozd (Das skythische Gräberfeld von Ozd [Bez. Mureș]). File de Istorie 3, 89-137.

Vulpe, Alexandru

1967 Necropola hallstattiana de la Ferigile - Monografie Arheologica. Biblioteca de Arhceologie 11. Bucuresti.

Westhausen, IMKe

2018 Early Iron Age hoards between Brittany and the Carpathian Basin - a preliminary review. Archaeologica Hereditas 13, 135-148. 


\title{
A Middle Iron Age assemblage of finds from Mezőzombor, NE Hungary
}

\author{
Péter Mogyorós - Gábor Bakos
}

In the autumn of 2018, a Middle Iron Age assemblage made out of bronze finds, iron fragments and amber beads had been found in Mezőzombor-Békás-ér in the northern part of the Great Hungarian Plain (Figs 1-2). The artefacts were scattered in a $5 \mathrm{~m}^{2}$ area between the depths of $0-25 \mathrm{~cm}$. The original context of the objects is uncertain, it had been disturbed by ploughing.

Among the different type of objects in the assemblage some have analogies in this region, these are the bronze rings with eyelets, the open-ended circular jewellery with conical ends, the star shaped bronze button and the amber beads. Other types, such as the twisted neckring with eyelet, the bronze rings with extensions and the perforated bronze discs were so far extremely rare or unknown from the Middle Iron Age of eastern Hungarian area. The bronze pendant with the cattle heads and the small iron rod has no exact analogy. There is also a small button among the presented finds, but it was not uncovered together with the other artefacts (Fig. 2, 5).

The twisted neckrings with eyelets were popular during the Urnfield period of Central Europe, during the Hallstatt period their numbers had dropped in the Carpathian Basin (Fig. 2, 2). In East Hungary from the $7^{\text {th }}$ century BC the wearing of neckrings was not common at all. In the Balkan during the $7-6^{\text {th }}$ centuries $\mathrm{BC}$ this type was still frequent. In the steppes these appear later in the $6-4^{\text {th }}$ centuries BC. Typologically the closest analogy to the neckring of Mezőzombor is known from the cemetery of Ciumbrud, both of these have similar widening ends.

The open-ended circular jewellery with conical ends were usual grave accessories of the Ciumbrud group's burials between the middle of the $7^{\text {th }}$ century $\mathrm{BC}$ and the middle of the $6^{\text {th }}$ century BC (Fig. 2, 3). From here the wearing of this type spread to the East Hungarian sites of the Vekerzug culture and to the Early Iron Age cemetery of Donja Dolina, later from the $6^{\text {th }}$ century $\mathrm{BC}$ these also appeared in the forest steppe region. According to the context of the analogies from Transylvania and Donja Dolina this type can be interpreted as earrings or maybe hairrings. In the forest steppe the representatives of the conical ended jewellery appears as armrings. In the sites of the Vekerzug culture these finds came from cremation burials so their wearing context is unknown. Judging by its diameter the one from Mezőzombor can be interpreted as an earring.

Star shaped buttons decorated with concentric circles were extremely rare finds of the Carpathian Basin (Fig. 2, 4). So far, the dateable analogies are known from the middle of the $7^{\text {th }}$ century BC and the middle of the $6^{\text {th }}$ century BC. Some researchers interpreted this type as horse equipment others rather believed it to be belt or scabbard fittings. Judg- ing by the finds from Grave 7 in Teiuș and Grave 6 in Budeşti-Fînaţe the latter statement is more acceptable.

Bronze rings with eyelets appear most frequently in the sites of the Vekerzug culture and the Ciumbrud group (Fig. 2, 6-9; Fig. 3, 3). These could also be find in the West Podolian group, the Ferigile culture and also on some sites west from the Vekerzug culture. This type can be dated to the $7-5^{\text {th }}$ centuries BC. Some archaeologists think of these finds as horse equipment others as pendants or clothing decorations. Judging by the finds of Grave 34 in Törökszentmiklós-Surján-Újtelep and Grave 3 Budeşti-Fînaţe the latter interpretation is more acceptable.

Rare finds are the bronze rings with extensions on their sides (Fig. 2, 10-13; Fig. 3, 1-2). These can be dated to the Hallstatt period. Their analogies can be found in Transylvania in the Balkan and even in Thessaly. In the case of this there are also researchers who interpret these artefacts as horse equipment and others who see them as part of the clothing. There are not many burials where the exact context is known, but judging by the find from Grave 6 in Ozd again the latter explanation is more certain.

Analogies of the perforated bronze discs with a handle are known from Moravia, the eastern parts of the Alps and the western half of the Carpathian Basin during the Urnfield and Hallstatt periods (Fig. 2, 14-19). These are interpreted as pendants. There are some occurrences east from the sites of the Urnfield and then later Hallstatt cultures, similarly to the discs in Mezőzombor these are missing any handles too. Judging by the finds of grave 10 in Donja Dolina, Greda des Mato Petrović sen and Grave 3 in Budești-Fînaţe this type can be classified as clothing decorations on the chest.

The bronze pendant with the cattle heads and the small iron rod between them has no exact analogies (Fig. 2, 1; Fig. 4). Looking at its appearance it can be seen similar to the bronze pendant from Grave 3 in Budeşti-Fînaţe, both seem to be assembled by bronze rings with eyelets. However, that find is also unique. The depiction of cattle is not at all common in the eastern part of the Carpathian Basin during the Early and Middle Iron Age, it is rather more frequent west from the Great Hungarian Plain in the sites of the Hallstatt culture. Another unique element of the pendant from Mezözombor is the fact that amber beads were all over it when the assemblage was uncovered (Fig. 2, 22). It is possible to assume that these beads decorated the pendant.

The assemblage can be dated to the second half of the $7^{\text {th }}$ century and the first half of the $6^{\text {th }}$ century BC, this is the period when the early sites of the Vekerzug culture were present in the region. The conical ended earrings, the bronze rings with eyelets and the star shaped buttons did not appeared in the Great Hungarian Plain before the second half 
of the $7^{\text {th }}$ century. The other end of this interval is not that certain, it is determined by the star shaped button, however this type does not have a high dating value due to it having only a few analogies.

According to the analogies of all the different type of artefacts in the assemblage these can be interpreted as clothing decorations. Judging by the signs of wear on the finds it is clear that these originally were not made to be buried.

Since the original context of assemblage is unknown it cannot be certainly established if the artefacts were buried as a hoard or as grave accessories. Hoards made out of metal jewelleries and clothing decorations occurred in the sites of the Eastern Hallstatt culture in Moravia and the western part of the Carpathian Basin. But hoards are not characteristic to the eastern part of the Carpathian Basin in the $7^{\text {th }}$ and $6^{\text {th }}$ centuries BC.

On most of the artefacts in the assemblage of Mezözombor burn signs could have been observed. This can be the result of cremation burials; this rite was frequent during the Middle Iron Age in the region. Judging by the burn signs and the lack of hoards in the East Carpathian Bason it is possible to assume that the finds in Mezözombor were grave goods.

Open Access. A cikk a Creative Commons Attribution 4.0 International License (https://creativecommons.org/licenses/by/4.0) feltételei szerint publikált Open Access közlemény, melynek szellemében a cikk bármilyen médiumban szabadon felhasználható, megosztható és újraközölhető, feltéve, hogy az eredeti szerző és a közlés helye, illetve a CC License linkje és az esetlegesen végrehajtott módosítások feltüntetésre kerülnek. (SID_1) 